IRSH 52 (2007), pp. 29I-305 DOI: I0.10I7/S0020859007003252

(C) 2007 Internationaal Instituut voor Sociale Geschiedenis

\title{
Humour and Protest: Jokes under Communism
}

\author{
Christie Davies
}

Summary: The largest corpus of jokes we have ridiculing both rulers and a political system comes from the former Soviet Union and the then communist countries of eastern Europe. These forbidden jokes were important to those who told them at some risk to themselves. They can be construed as a form of protest, but the relationship between jokes and protest is not a simple one. The number of jokes told was greater, and the telling more open, in the later years of the regimes than in the earlier years of terror and extreme hardship. The number of jokes is a product of the extensiveness of political control, not its intensity. Such jokes probably have no effect either in undermining a regime or in acting as a stabilizing safety valve. However, they were a quiet protest, an indication that the political system lacked stability and could collapse quickly.

\section{INTRODUCTION}

The longest, largest and most widespread instance of humour as social protest is to be found in the political jokes told in the former Soviet Union throughout its history, and between the mid-I940s and I989 in the communist countries of eastern Europe which it had occupied and dominated during this time. They were mocking and critical, not just of political leaders as individuals, but of the entire social and political system and its ideology, rituals, and myths. In eastern Europe and the lesser Soviet Republics the jokes were also strongly anti-Russian, levelled against the imperial nation by which they felt doubly oppressed, both as foreign ruler and occupier and as the upholder of an imposed and resented social and political system. The jokes were a genuinely people's humour, an authentic folk humour, for they were totally excluded from the mass media; they were "whispered jokes" that could not be published in the countries where they were told. They were the jokes of the powerless against the absolutely powerful. They were a collective product, for jokes have no authors and no discernible origin.

The existence of such a large, and in all senses popular, culture of humour is an important social fact in and of itself. It is clearly related to popular protest and resistance but the nature of the relationship is very 
problematic and will be considered at length later. First, though, it is necessary to discuss the jokes themselves, why we should see them as important, the circumstances of their telling, and the joke-tellers' relationship to the political hierarchy.

\section{THE IMPORTANCE OF THE JOKES}

Jokes under communism had a far greater personal, political, intellectual, and historical importance than is the case with political jokes told in traditional or democratic societies, or indeed under autocratic regimes that suppress opposition but do not seek to control and transform independent social institutions or to insist on enthusiasm. The personal importance of the jokes can be inferred from the risks that so many individuals took in telling and circulating them when they knew that being reported to the authorities could result in possible imprisonment or deportation and even death. ${ }^{\mathrm{I}}$ Indeed there are jokes that refer directly to the spying on, arrest, trial, and punishment of joke-tellers. ${ }^{2}$

That people took such risks is both an indication of the importance the jokes had for them and of the strong and interlocking networks of interpersonal trust and solidarity that they had created, which provided them with some degree of independence from an overwhelmingly powerful state. ${ }^{3}$ In Estonia, the philologist Jüri Viikberg wrote down and saved 4,000 "bilious and offensive anti-Soviet jokes" between I 960 and 1986, which were then secretly stored for the Estonian folklore archives, waiting for the coming of a free and independent Estonia. ${ }^{4}$ Jokes mattered.

For the authorities and particularly for the secret police, the Cheka, the OGPU, the NKVD, and the KGB, henceforth referred to collectively as the KGB, the jokes were also important, both as a form of subversion and opposition reported by informers and as a source of information about public opinion. The secret police regularly collected and sometimes repressed political jokes. Indeed the KGB files may well turn out to be

I. Peter Deriabin and Frank Gibney, The Secret World (London, I960), appendix giving sample reports on joke-tellers filed by KGB case officers; Elliott Oring, "Risky Business, Political Jokes Under Repressive Regimes", Western Folklore, 63 (2004), pp. 209-236.

2. Robert Cochran, “'What Courage!': Romanian 'Our Leader' Jokes”, The Journal of American Folklore, I 42:405 (1989), pp. 259-279, 270; Antoine and Philippe Meyer, Le communisme est-il soluble dans l'alcool (Paris, I978), p. i 10.

3. For Stalin's time see Robert Thurston, "Social Dimensions of Stalinist Rule: Humor and Terror in the USSR, I935-194I", Journal of Social History, 25 (I99I), pp. 54I-562, 54I, 544, 550. For the later period see Vladimir Shlapentokh, Soviet Intellectuals and Political Power: The PostStalin Era (London, I990), p. 72.

4. Júri Viikberg, Anecdotes about Soviet Power and their Leaders, Collected from Estonia, 1960I986 (Talinn, I997), p. 3, see also Arvo Krikmann, Netinalju Stalinist (Tartu, 2004), p. 38; and idem, "Jokes in Soviet Estonia" (paper presented at the I8th ISHS conference at the Danish University of Education, Copenhagen, July 2006), p. I. 
Who built the White Sea-Baltic Canal?

On the right bank those who told anecdotes. On the left bank those who listened.

Figure I. Joke about the punishing of jokers.

the best source of ethnographic data on anti-Soviet humorous folklore in general, including graffiti, parody, and chastushki (satirical songs or limericks), since all other records of these were, of necessity, censored and bowdlerized.' If the jokes are seen as an indication of popular alienation, then the secret police were right to take them seriously as a political phenomenon, particularly in a society where no other measures of public opinion were possible.

The jokes were so much a part of everyday understanding that people in the Soviet Union and eastern Europe would routinely use them to make a point. This was not just to render an account more entertaining, but because, as one Uzbek put it, an anecdote could contain "the whole tragedy and drama of an event". ${ }^{6}$ Jokes were used because they had force as well as because they gave pleasure. Jokes were remembered and transmitted better than other aspects of informal culture. ${ }^{7}$ Jokes were used under communism as a means of conveying insight, far more than they are or ever have been in other kinds of society.

\section{JOKES OF THE TIME OF TERROR AND JOKES OF THE TIME OF ROUTINE OPPRESSION}

The political jokes of the Soviet Union and its satellites can for convenience be roughly divided into two eras, the time of terror, roughly $1928-1956$, and the time of routine oppression, $1956-1985$. Many political jokes were, of course, invented and told both before and after these two periods. However, there is a scarcity of contemporary accounts for the earlier period and it is difficult to know whether, say, jokes about Lenin were invented during his time or were a product of the later cult of Lenin culminating in the hundredth anniversary of his birth in 1970 . Likewise, there are many jokes from the Gorbachev era, immediately prior to the

5. Sarah Davies, Popular Opinion in Stalin's Russia, Terror, Propaganda and Dissent, 1934-I94I (Cambridge, 1997); Sheila Fitzpatrick, Everyday Stalinism, Ordinary Life in Extraordinary Times: Soviet Russia in the I930s (New York, 1999).

6. Krikmann, Netinaliu Stalinist, p. 24I.

7. Fitzpatrick, Everyday Stalinism, p. I83. 
final demise of communism, first in eastern Europe and then in the Soviet Union. However, these are fewer in number, particularly after it had become possible to discuss political issues freely in public and the jokes were co-opted by the elite, being used in speeches by Gorbachev and even by leading figures in the KGB. ${ }^{8}$

Both the content of the jokes of the time of terror and the circumstances of their telling differed from those of the later period. It is hardly surprising, since the time of terror, which I have dated from Stalin's consolidation of power by 1928 to Khruschev's denunciation of terror in his speech to the XXth Congress of the CPSU in 1956, saw the killing of many millions of innocent people and the arbitrary imprisonment and exile of tens of millions of others. 9 The era from Khrushchev to Chernenko was undoubtedly repressive and oppressive but it was not characterized by the same level of ruthless and sometimes random callousness.

The jokes of the time of terror refer directly ${ }^{10}$ to the crushing of the peasants with forced collectivization, the deportation of the kulaks, and the deliberately created famines. ${ }^{\text {I }}$ They refer to the purges of engineers, intellectuals, and Party members in the $1930 \mathrm{O},{ }^{12}$ to the anti-Semitic persecutions of the Jews, particularly in 1946-1953, the black years of Soviet Jewry, ${ }^{13}$ and to the torture, executions, and labour camps. We may also include jokes about the harsh labour laws of the period I940-1956, when workers were forbidden to change their jobs and were subject to criminal penalties (including the labour camp) for such irregularities as being more than twenty minutes late for work. ${ }^{14}$ There was clearly much for members of all classes and nations to protest about and we can readily document from independent sources the horrors to which the jokes refer. Yet there were far fewer jokes about Stalin, "Koba the Dread", the cunning, the cruel, the ruthless, the monster, than about Khruschev, Brezhnev, Andropov, and Chernenko (whom the jokes depicted as buffoons), fewer jokes about Stalin's violent times than about their routine oppression. ${ }^{\text {Is }}$

8. Christopher Andrew and Vasili Mitrokhin, The Mitrokhin Archive, II (London, 2005), p. 476; Nikolai Zlobin, "Humor as Political Protest", Demokratizatsiya, 4 (1996), pp. 223-23I, 224. 9. R.J. Rummel, Lethal Politics, Soviet Genocide and Mass Murder (New Brunswick, NJ, 1990). ı. See Bruce Adams, Tiny Revolutions in Russia, Twentieth Century Soviet and Russian History in Anecdotes (New York, 2005); William Henry Chamberlin, “The Anecdote': Unrationed Soviet Humor", Russian Review, I6:3 (1957), pp. 27-34; David A.Harris and Izrail Rabinovich, The Jokes of Repression, The Humour of Soviet Jews (Northvale, NJ, I 988); I.D.W. Talmadge, "The Enjoyment of Laughter in Russia", Russian Review, 2:2 (1943), pp. 45-5 I.

I I. See Miron Dolon, Execution by Hunger (New York, 1985 ).

I2. See Robert Conquest, The Great Terror: Stalin's Purge of the Thirties (Harmondsworth, 197I); Boris Levytsky, The Uses of Terror (London, 1971).

I3. See Anatoly Vaksberg, Stalin against the Jews (New York, 1994).

I4. See S. Davies, Popular Opinion in Stalin's Russia, pp. I 5, 46-47; Victor Zaslavsky, The NeoStalinist State: Class, Ethnicity and Consensus in Soviet Society (New York, 1982), pp. 46-47. I 5. Krikmann, Jokes in Soviet Estonia, pp. 2-3; Victor Raskin, Semantic Mechanisms of Humor 
What is the difference between India and Russia?

In India one man starves for the people, and in Russia the people starve for one man.

Two Russians discussed who was the greater man, Stalin or President Hoover.

"Hoover taught the Americans not to drink", says one.

"Yes", replies the other, "but Stalin taught the Russians not to eat".

A Russian Jew was walking through the suburbs of Moscow when a car stopped. Suddenly, a man was thrown out at the side of the road and the car sped off. The Jew ran over and saw that it was his old friend Moishe who had been beaten almost to death by the KGB and was nearly unconscious, his eyes opening and closing.

"Moishe, Moishe", he cried, "It's me, Abram. Don't you remember me? We were in Auschwitz together."

"Ah", said Moishe dreamily, "Ah yes, Auschwitz".

Figure 2. Typical examples of jokes of the time of terror.

The smaller number of political jokes from the time of terror relative to its successor, the Khruschev to Chernenko era, creates problems for the simple version of the thesis that the jokes were a form of protest. This view has been most strongly advocated by the leading anthropologist of jokes, Alan Dundes, who has written that "the more repressive the regime, the more numerous the political jokes", ${ }^{16}$ and in Banc and Dundes that "the more repressive the ideology and system the more ingenious and clever the political wit". ${ }^{17}$ However, far more political jokes seem to have been generated in the less oppressive years, $1956-1985$, building up steadily to a peak in the later years of the Brezhnev era at the beginning of the $1980{ }^{18}{ }^{18}$

Dundes's proposition is clearly false, or at the very least there is another more powerful factor at work, namely that it had become safer to tell

(Dordrecht, 1985), pp. 23-24; Alexei Yurchak, "The Cynical Reason of Late Socialism: Power, Pretence and the Anekdot”, Public Culture, 9 (1997), p. 175. It should be kept in mind that earlier jokes may have not been recorded and that the later ones will include adapted, recycled material. I6. Alan Dundes, "Laughter Behind the Iron Curtain”, Ukrainian Quarterly, 27 (197 I), pp. 5059,5 I.

17. C. Banc (pseudonym) and Alan Dundes, First Prize: Fifteen Years! (Cranbury, NJ, 1986), p. I4.

I8. See n. Is. 
political jokes, since the chances of being apprehended were lower and the penalties less drastic. Even during the thaw of the late I950s there was a marked growth in the relaxed telling of political jokes. ${ }^{19}$ Good joke-tellers were popular and esteemed. By the late i960s it was common at an intermission in any gathering to reel out a string of anekdoty, the political jokes, and this was even more open and common by the late $1970 .^{20}$ In Bulgaria in the early I980s my English-speaking colleagues would openly exchange jokes with me in a crowded restaurant, the only precaution being observed that Brezhnev was referred to as "Mister B", lest the laughter following his name should arouse suspicion. We were a long way from the time when one could be arrested even for smiling at a political joke told by strangers at an adjoining table. ${ }^{21}$ Jokes no longer had to be told in the seclusion of the bathroom, as had been the case when exchanged by intellectuals during the time of terror. ${ }^{22}$ Yet it is also clear that the jokes travelled easily between the less repressive communist countries such as Poland and Hungary and a very repressive one such as Ceausescu's Romania, the source of the jokes studied by Dundes. ${ }^{23}$

\section{JOKES AS A PRODUCT OF THE BREADTH OF OPPRESSION.}

The link between repression and the flourishing of jokes is to be sought not in the intensity of the repression but in its extensiveness. In the last years of Franco's rule in Spain there were many political jokes that mocked the Candillo himself, ${ }^{24}$ but neither in numbers nor in intricacy could they match those being told in the Soviet Republics and eastern Europe. There was less to joke about. The Franco regime did not seek to control most non-political activities, nor to establish a monopoly over economic transactions. Franquismo was not an ideology but the rule of a particular person and the Falanga was not a ruling party in the communist sense. ${ }^{25}$ In consequence Spain shared with the communist countries some of the jokes

19. Elena F. Hellberg, "The Other Way Round: The Jokelore of Radio Yerevan", ARV Scandinavian Yearbook of Folklore, 4I (1985), pp. 89-104, 92-93.

20. Alex Beam, Introduction to Arie Zand, Political Jokes of Leningrad (Austin, TX, I982), pp. i-iii; Emil Draitser, Forbidden Laughter (Los Angeles, CA, I978), pp. 3-5; Shlapentokh, Soviet Intellectuals and Political Power, p. I I 4; Yurchak, "The Cynical Reason of Late Socialism”, pp.

I74, I79.

21. Conquest, The Great Terror, p. 423.

22. Joshua Rubinstein, The Life and Times of Ilya Ehrenburg (New York, I996), pp. 171-172. 23. Cochran, "What Courage!', p. 272. See also Dundes, Laughter Behind the Iron Curtain; Banc and Dundes, First Prize: Fifteen Years!

24. P. García (Jose García Martinez), Los Chistes de Franco (Madrid, 1977).

25. Stanley G. Payne, The Franco Regime 1936-1975 (London, 2000), pp. 622-627; Oriol

Pi-Sunyer, "Political Humor in a Dictatorial State: The Case of Spain", Ethnobistory, 24 (1977), pp. I79-190, I79. 
of the era of routine oppression, those about dim, limited, and eventually senile rulers, ${ }^{26}$ but there were very few political jokes of other more sophisticated kinds about economic or ideological or scientific matters.

Communism generated more and more sophisticated jokes because it sought to control so much, both materially and ideologically, giving rise to the possibility of political jokes about the absurdities of official science and history and of its detailed and endlessly reinterpreted ideology. Likewise communism demanded active unfreedom; where merely authoritarian regimes are content with acquiescence, communism demanded enthusiasm and compulsory participation and even belief in its newly minted rules and rituals, celebrations and processions, myths and exemplary stories, all of which became the subject of jokes. ${ }^{27}$

\section{JOKES : FROM SHORTAGES TO SHODDY}

The biggest topic of the jokes under communism was the ubiquitous shortages, the queuing in line for food and basic necessities, and the poor quality of housing and consumer goods $;{ }^{28}$ these were not economic jokes but political ones, since the state controlled the economy and claimed responsibility for the welfare of its citizens and repeatedly told them how well off they were. These jokes are continuous from the I920s to the I980s but there are once again two phases and two patterns of joking.

In the time of terror the standard of living for all except a highly privileged elite was extremely low. The independent economic life of the peasantry had been destroyed and in the towns wages forced down to the point where most of a family's income went on food and even then the people were hungry and sometimes close to starvation. ${ }^{29}$ Housing and working conditions were bad and collectivized agriculture could not provide enough food. The jokes reveal all these disasters of the everyday and are in contrast with the slogans that life was better and life was joyful in the egalitarian workers' state. The special and privileged position of a small Party elite who had access to unlimited food through multiple ration books, to special TORGSIN shops that sold luxuries, and to luxurious housing was also a subject of joking.

26. Stanley H. Brandes, "Peaceful Protest: Spanish Political Humor in a Time of Crisis", Western Folklore, 35 (1977), pp. 33 I-346, 335-337; Pi-Sunyer, "Political Humor in a Dictatorial State", pp. I $82-189$.

27. Adams, Tiny Revolutions in Russia; Nina Tumarkin, Lenin Lives!: The Lenin Cult in Soviet Russia (Cambridge, MA, 1984), pp. 263-269.

28. Adams, Tiny Revolutions in Russia, Banc and Dundes, First Prize: Fifteen Years!

29. S. Davies, Popular Opinion in Stalin's Russia, pp. 23-30, 109; Fitzpatrick, Everyday Stalinism, pp. 2-9; and see Lesley A Rimmel, "Another Kind of Fear: The Kirov Murder and the End of Bread Rationing in Leningrad”, Slavic Review, 56 (1997), pp. 48 I-489. 
Slogans and promises related to reality in a way that was absurd, a breeding ground for jokes as well as resentment.

Yet once again, more scarcity jokes seem to have been told under Khruschev and Brezhnev at a time when standards of living were rising and money wages rising even faster and the government was prepared to spend foreign currency on imported grain rather than allow starvation..$^{30}$ The jokes about the poor quality of goods and services and the necessity to import grain at least indicate that food and goods and services, albeit shoddy and inefficient, were available. But the modest improvements in people's standard of living may well have led to rising expectations and in turn to a new kind of popular discontent when these were not met. In the face of failure, the excuses made by and for a regime that owns all the means of production and boasts of its economic performance will not be believed by its own citizens, who neither chose it nor are able to make their own autonomous economic decisions.

\section{HUMOUR AND THE POLITICS OF BLAME}

The rulers of the Soviet Union consistently tried to pin the blame for economic failure, particularly in the production of consumer goods, on lower-level functionaries. These included petty bureaucrats, collective farmers, repair men, or even the workers in particular factories. Disgruntled individuals were encouraged to write and complain about low-level functionaries both to more powerful officials at the centre and to the press, which often published their letters. ${ }^{3 \mathrm{I}}$ What is more significant, though, is what was not printed, such as complaints about hunger, cold, shortages, official regulations. ${ }^{32}$ The tactic was to divert blame. All faults were local and the blame lay with erring individuals.

Official humour was an extension of this pattern, in which approved journals with sharp and prickly names such as Crocodile, Nettles, Porcupine, Hornet, Stag Beetle, Thistle, would publish satires and cartoons about those in the front line who had to deal directly with workers, clients, and customers. No-one powerful was ever mocked in this way, nor was the political and economic system, and editors could be sacked for getting too close to the boundary of the permissible. ${ }^{33}$

30. Richard V. Burks, "The Coming Crisis in the Soviet Union", in Alexander Shtromas and Morton Kaplan (eds), The Soviet Union and the Challenge of the Future, 4 vols, I (New York, 1989), pp. I I 5-165, I 22; Zaslavsky, The Neo-Stalinist State, pp. 52-53, I00, I 23.

31. S. Davies, Popular Opinion in Stalin's Russia, pp. 18, 31; Thurston, Social Dimensions of Stalinist Rule, pp. $55 \mathrm{I}-553$.

32. S. Davies, Popular Opinion in Stalin's Russia, p. 3 I.

33. Chamberlin, "The Anecdote", p. 27; Oring, "Risky Business", p. 216; Jacquin Sanders, "The Tactful Satirists", East Europe, I I:2 (1962), pp. 22-27; Jacquin Sanders, "The Seriousness of Humor: Political Satire in the Soviet Bloc", East Europe-Euromonitor, II (1982), pp. 2I-29; Talmadge, "The Enjoyment of Laughter in Russia”, p. 46. 
Can you wrap up an elephant in a newspaper?

You can if the paper contains the text of one of Khruschev's speeches

What is seven kilometres long and eats potatoes?

A Polish meat queue.

Why is the Soviet system superior to all others?

Because it successfully overcomes problems that no other system has.

When the Soviet Union bought wheat in Canada in 1964 a question was put to Radio

Armenia: Why were we able to buy wheat from Canada?

Due to the key shortcoming of capitalism - chronic overproduction.

Figure 3. Typical examples of jokes of the time of routine oppression.

The humour of the people was the opposite of this in two senses. First, there were numerous jokes about the ubiquitous scarcities, the blame for which the jokes clearly pinned on the system, the politicians, the Party, and the planners. The jokes mirror the resentful complaints to be found in the KBG files for the earlier period or the views expressed in the brief interval in 1968 when public opinion polls were allowed in Czechoslovakia; ${ }^{34}$ the people blamed their rulers, often harshly and abusively. The two kinds of humour are also opposites in another sense. The official humour was planned with a particular purpose in mind. It was intentional and tendentious, its authors more concerned to try to arouse scorn and indignation through ridicule than to be funny. Jokes are not like that. They have no authors and it is impossible to infer tone, purposes, and feelings from the text; these are a product of the telling and this can be highly varied. ${ }^{35}$

\section{JOKES AND PROTEST}

The points made above about the anonymity and ambiguousness of jokes, qualities of all jokes, not just political ones, creates serious problems for

34. S. Davies, Popular Opinion in Stalin's Russia, pp. 17, I40-141; Fitzpatrick, Everyday Stalinism, p. I80; Rimmel, "Another Kind of Fear", pp. 493-499; and see Jaroslaw Pieckalkiewicz, Public Opinion Polling in Czechoslovakia (New York, 1972).

35. Christie Davies, The Mirth of Nations (New Brunswick, NJ, 2002), pp. 22 I-222, 227-228. 
those who see a clear straightforward link between jokes and protest. We can see this, in another parallel case, that of the Nazi occupation of many of Europe's countries during World War II, which produced numbers of so-called "resistance jokes". ${ }^{36}$ After the war many would recall these jokes with pleasure and cite them as proof that they too had been resisters, when in truth they, like most of their fellow citizens, had lived in the grey area of more or less collaboration.

The view of jokes as resistance was strongly propounded by Obdrlik ${ }^{37}$ in relation to the resistance movement in the Czech lands. He claimed that the numerous jokes circulating there about the German occupation were proof of the existence of a strong and vigorous resistance movement, whose morale was sustained by the jokes, whilst that of the enemy was undermined. However, Bryant ${ }^{38}$ was able to show later that the Czech resistance movement had been negligible in size, organization, and impact and had achieved nothing; political jokes in circulation were regularly reported back to the Czech government in exile in London as an index of resistance but there was little else to report.

Many other humour scholars have asserted, usually without evidence, that humour is an effective form of resistance, a boost for the oppressed, and an underminer of their oppressors. ${ }^{39}$ Others have denied the effectiveness of jokes and even claimed that jokes are a safety valve that help oppressive regimes to survive and that it is counter-productive to try to suppress them..$^{\circ}$ It is extremely unlikely that, taken in aggregate, jokes have any significant effect one way or the other, particularly when compared with other stronger social forces. No such effects have ever been demonstrated at a macro-level. Jokes are a thermometer not a thermostat; they can be used as an indication of what is happening in a society but they do not feed back into the social processes that generated them to any significant extent.

In all face-to-face groups humour is used, often effectively, in

36. André Clément, Les 100 meilleures histoires de l'occupation (Paris, 1945); Kathleen Stokker, Folklore Fights the Nazis, Humor in Occupied Norway, I940-1945 (Cranbury, NJ, 1995), pp. $22-23$.

37. Antonin J. Obrdlik, “Gallows Humor': A Sociological Phenomenon”, The American Journal of Sociology, 45:5 (1942), pp. 709-716, 709, 71 2, 716.

38. Chad Bryant, "The Language of Resistance: Czech Jokes and Joke-Telling under Nazi Occupation, I943-45”, Journal of Contemporary History, 4I (2006), pp. I33-I 5 I, I33-I39.

39. George Mikes, foreword to Stephen Lukes and Itzhak Galnoor, No Laughing Matter: A Collection of Political Jokes (New York, 1985), p. vii; Pi-Sunyer, "Political Humor in a Dictatorial State", pp. 183-187; Zlobin, "Humor as Political Protest", p. 223.

40. Cochrane, "What Courage!", p. 272; Emil Draitser, "Soviet Underground Jokes as a Means of Entertainment”, Journal of Popular Culture, 23 (I989) pp. II7-I25, I 8; Alexander Rose, "When Politics is a Laughing Matter", Policy Review, I I0 (2001-2002), pp. 50-71, 7-8; Hans Speier, "Wit and Politics: An Essay on Laughter and Power", American Journal of Sociology, I03:5 (1998) pp. I352-I40I, I395. 
conjunction with other techniques and mechanisms, both to maintain the identity of a group and the furtherance of its goals. This is true not just of groups involved in protest but of groups involved in oppression, of groups in the workplace, and of groups involved in leisure activities. It would be wrong to infer automatically from this that the existence of a large anonymous joke-cycle critical of a regime is an index of protest.

\section{JOKES AND CARNIVAL}

There is a parallel between the jokes told under communism and the carnival behaviour of medieval times when the rites and rituals of the Church were burlesqued, the social distance between the high and the lowly diminished, the mighty mocked and the world turned upside down. ${ }^{4 \mathrm{I}}$

In many ways this is what jokes under communism did, for slogans, ideological arguments, and political catechisms were parodied and inverted, solemn political rituals and uplifting tales about heroes such as Chapaev, or cult figures, notably Lenin, were reduced to foolishness, or even nastiness, and current leaders shown as complete fools. ${ }^{42}$ Indeed it has been suggested that when Bakhtin wrote about the medieval carnival, in many ways he had in mind the popular humorous culture of the Soviet Union, a subject about which it was forbidden to write. ${ }^{43}$

Carnivals may well be benign events that, though the antithesis of the social order, reinforce it. Hans Speir uses this analogy when he argues that political jokes are a safety valve. ${ }^{44}$ Yet can it be shown that this is true of carnivals in general? The regime certainly did not think so, for it fostered blasphemous carnivals got up by communist aktivists as a political weapon to undermine the Russian Orthodox church. ${ }^{45}$ Also the carnivals of the type of which Bakhtin speaks were regular, even scheduled, licensed events. Soviet joke-telling in Bakhtin's time was private, forbidden, and often furtive, a subject for surveillance, licence not licensed. The analogy is dubious.

The same point may be made in relation to the view that the jokes were like those told about priests by faithful rural church-goers in Tsarist Russia or in Catholic Bavaria, or about trickster but loyal

4I. Mikhail Bakhtin, Rabelais and his World (Cambridge, MA, I985), pp. 71-96.

42. See S. Davies, Popular Opinion in Stalin's Russia, pp. 174-177; see also Michael Schiff, Radio Eriwans, Auslands-Program (Frankfurt, 1975); idem, Radio Eriwans antwortet (Frankfurt, 1978).

43. Katerina Clark and Michael Holquist, Mikhail Bakhtin (Cambridge, MA, I984), pp. 3073 I4; Sue Vice, Introducing Bakhtin (Manchester, 1997), pp. I 52-I 54.

44. Speir, "Wit and Politics", p. I395.

45. Christel Lane, The Rites of Rulers: Ritual in Industrial Society in the Soviet Case (Cambridge, I98I), p. I30. 
servants making fools of their masters. ${ }^{46}$ No doubt such jokes can occur in a local social order legitimized by custom and tradition and circulate among priests and masters themselves, who do not find them threatening. But how would we regard such jokes if told in a society riven by intense class antagonisms or anti-clericalism, where priests and masters are loathed?

\section{JOKES AS A SUBSTITUTE FOR RESISTANCE AND THE COLLAPSE OF THE OLD REGIME}

Some have argued that jokes are even a substitute for protest and resistance to harsh regimes, not just a safety valve or a pain-killer but an opiate, and indeed follow this up with the supporting claim that when the true mutiny and resistance starts the jokes cease. ${ }^{47}$ The moral, though, is not that one is a substitute for the other but that external circumstances dictate which is possible. What is far more significant is the speed with which the jokers switch to overt opposition when the power of the oppressor is removed or relaxed, an indication that the jokes were part of a protest but one circumscribed by circumstance. Should there be a shift in the balance of power in favour of the oppressed, far from abandoning their political jokes, they may well make them part of their new and more overt and vigorous forms of resistance.

This is what happened with the growth of a more confident and effective Norwegian resistance movement in the latter years of World War II and at the time of open public protests in Czechoslovakia in 1968 or in Poland. ${ }^{4}$ The jokes now became attached to and incorporated in a serious rhetoric of resistance. Jokes do not make the rhetoric more persuasive or meaningful but they enliven it. They are not a sword but they are attractive decoration on the scabbard. The jokes of resentful resignation quickly become the jokes that accompany active resistance.

Some humour scholars have regarded those who told jokes under communism as exhibiting a "humour that has ceased to struggle", 49 the humour of cynical and alienated people no longer able to protest or resist, unable even to envisage an alternative to the immutable, omnipresent, overwhelmingly powerful political system that dominated every aspect of their lives. In the time of terror they had been demoralized and by the time of routine oppression they had come to take the system for granted, as

46. Draitser, "Soviet Underground Jokes", p. i 18.

47. Cochran, "What Courage!", p. 272 ; Speir, "Wit and Politics", p. I 399. See also discussion in Oring, "Risky Business", pp. 222-223.

48. Robert Littell (ed.), The Czech Black Book, Prepared by the Institute of History of the Czechoslovak Academy of Sciences (London, 1969), p. I I ; Stokker, Folklore Fights the Nazis, pp. 207-210. 
inevitable and as ever-lasting. ${ }^{\circ} \mathrm{It}$ is difficult to reconcile this view with the sheer revolutionary speed with which communist rule in eastern Europe collapsed in I 989 and in the Soviet Union itself in I99I. It proved to have been not a stable system but a rigid one in unstable equilibrium that, once disturbed, was destroyed; the jokes were a symptom of this, a predictor of the collapse, a protest against its lack of legitimacy.

Once Gorbachev, who had no idea he was opening the way to collapse, had made it clear to the east European leadership in 1985 and in 1986 that he would no longer use the Soviet army to prop up the east European regimes, they were finished, at least once their peoples had worked out that this was the case. Jaruselski dared not reintroduce martial law in Poland in I 989 for fear of a bloodbath, so he permitted a rigged election. Solidarity won an overwhelming victory. Next the Berlin Wall came down and the communist regime in East Germany collapsed and within a matter of weeks all the rest had gone. Only external military force had ever kept them in power. Within two years the Ukraine, the Baltic states, and all the other non-Russian republics had seceded from the Soviet Union and Russia itself had ceased to be communist. The alternative future envisaged in the jokes had happened.

Well before the "Autumn of the Nations" in 1989 there had been times of public and sometimes violent protest, notably in East Germany in 1953 , Hungary in 1956, Czechoslovakia in 1968, in Poland repeatedly, which were only crushed by Soviet tanks or the threat of tanks. Again what was striking was the speed of the collapse; in the Hungarian Revolution the old order ceased in a matter of days. ${ }^{51}$ Between revolts the oppressed told political jokes about communism. The jokes were not a substitute for protest but an interim protest until the next opportunity for something more vigorous. Here at least, jokes are a continuation of protest by other means.

We can even see this pattern in the Soviet Union in the time of terror in 1939-I94I. There existed at this time an extensive humorous folklore that spoke of the overthrowing of Soviet power by war. ${ }^{52}$ In I94 I the peoples of the Ukraine, Byelorussia, the Baltic states, and the first occupied Russian territories at first welcomed the German invader and even fired on the retreating Soviet army. In the Baltic states uprisings and shooting began well before the Germans arrived. After the war local partisan warfare against the Soviet authorities continued until the early i950s. Entire Soviet nationalities were deported lest they

49. Yurchak, "The Cynical Reason of Late Socialism", p. I63.

50. Nicolai Tolstoy, Stalin's Secret War (London, I98I), pp. I 50-I 54; Yurchak, "The Cynical Reason of Late Socialism", p. I66.

5I. Alexander Shtromas, Political Change and Social Development: The Case of the Soviet Union (Frankfurt, 1981), p. Io0.

52. S. Davies, Popular Opinion in Stalin's Russia, pp. 94-ıо . 
do the same.53 A million Soviet citizens changed sides and fought for the Germans. ${ }^{54}$ Jokes and apparent apathy can quickly turn to open conflict. Only a realization that the Nazis had come to exploit and murder the inhabitants of the conquered territories, whom they treated as sub-human Slavs, and a very rapid switch by Stalin away from the previous ideology to Russian patriotism and tradition enabled the regime to survive and eventually win.

\section{POLITICAL JOKES AND POLITICAL PREDICTIONS}

It is not just a case of being wise after the event. During the course of I98I-I982 Alexander Shtromas, then lecturing in Peace Studies in England, convinced me that the jokes were not only a protest of the weak but a harbinger of collapse. Professor Shtromas followed his 1981 book, Political Change and Social Development: The Case of the Soviet Union, about how the collapse would come aboutss with a plan for a large conference called "The Fall of the Soviet Empire", which was held in Geneva in 1985 . He invited me to give a paper there "Humour for the Future and the Future for Humor", ${ }^{6} 6$ which proved to be somewhat prescient. Most Sovietologists preferred to extol the system's stability, legitimacy, and durability. Yet Shtromas, who was condemned and criticized at the time, was within six years proved right, and the jokes were part of his case, not as a cause of the collapse, but as a form of protest that indicated a danger that the Sovietologists could not see.

Now that the Soviet government files, including some of the KGB files, have been examined by many scholars, we can see why the jokes were a good index of what was happening. Between times of overt protest the jokes flourished and lived alongside other totally serious expressions of low-level dissent and of passive resistance, the weapons of the weak. 57 The jokes were the transportable, context-free, pleasurable aspect of this defiance that we know about; the rest was only observed and observable on a large scale by the secret police. The jokes were the tip of an iceberg of discontent. It is this that enables us to

53. Rummel, Lethal Politics, pp. 57-58; Alexander Shtromas, "The Baltic States as Soviet Republics: Tensions and Contradictions", in Graham Smith (ed.), The Baltic States: The National Self-Determination of Estonia, Latvia and Lithuania (Basingstoke, 1996), pp. 86-i I7, 89-90; Tolstoy, Stalin's Secret War, p. 242.

54. See Catherine Andreyev, Vlasov and the Russian Liberation Movement (Cambridge, 1989).

55. Shtromas, Political Change and Social Development.

56. Christie Davies, "Humor for the Future and a Future for Humor", in Shtromas and Kaplan, The Soviet Union and the Challenge of the Future, III, pp. 299-319. The paper was submitted in 1985. The conference papers were published in 1989 in four volumes of about 750 pages each. 57. Cf. James C. Scott, Weapons of the Weak (New Haven, CT, 1985). 
calibrate the jokes as an aggregate phenomenon and to confirm our earlier suspicions. We cannot do this from the texts of the jokes alone, for, after all, even the members of the KGB enjoyed them, nor from the post-Soviet reminiscences of those who joked, whose memories may be selective or atypical or affected by later events. ${ }^{8}$ Rather it is the evidence of how the joke-tellers behaved in others ways at the time that enables us to define the jokes as protest and to see why they were a good predictor of the, to most observers quite unexpected, end of communism in Europe.

58. Deriabin and Gibney, The Secret World, pp. 38, 61, I4I, 175, 220, 227; Thurston, Social Dimensions of Stalinist Rule, p. 594. 